Brit. J. industr. Med., 1948, 5, 16.

\title{
SOME PHYSIOLOGICAL OBSERVATIONS ON WEST AFRICAN COAL MINERS
}

\author{
BY
}

\author{
W. S. S. LADELL
}

From the Colonial Medical Research Committee Scheme for Research in Hot Climate Physiology, Medical School, Yaba, Lagos, Nigeria

(RECEIVED FOR PUBLICATION, OCTOBER 15, 1947)

The Enugu Colliery is the only extensive underground mine in Nigeria; it is not deep, being worked from adits, and the greatest cover is only 400 feet. It is almost entirely unmechanized, and has a total underground labour force of 6,000 men recruited locally. The temperatures within the mine are never excessive in comparison, for example, with those in the Kolar gold mines (Caplan, 1943); but the relative humidity is above 90 per cent. in many places and 100 per cent. in some. There is no piped air to the faces, and the air movement, except in the larger galleries and roads, is very low; representative figures are given in Table 1. Although no casualties from the heat have been reported, it was thought worth while to make some observations upon the miners to see how they were reacting to these quite severe conditions. The results of some preliminary observations are now reported.

\section{Results}

Rectal Temperature Changes.-Rectal temperature measurements were made on 141 men, all either hewers or tubmen, before, during, and after an eight-hour shift, 7 a.m. to 3 p.m. In addition 11 more men were observed within the mine only. The time of each observation was noted. Each man's working conditions were determined, the air temperature and humidity were measured with a sling psychrometer, and the air movement was measured by means of a high temperature ( 130 to $125^{\circ} \mathrm{F}$.) silvered katathermometer. Observations were made in five different districts; owing to the difficulty of reaching the men at their work, it was necessary to make all the observations for one district on the same day ; this was not satisfactory statistically, but the external climatic conditions during the investigation did not vary at mid-day more than $2^{\circ} \mathrm{F}$. from a mean dry-bulb temperature of $83^{\circ} \mathrm{F}$., and a mean wetbulb temperature of $76.5^{\circ} \mathrm{F}$.

(a) Mid-shift Temperatures.-Mid-shift rectal temperatures were taken chiefly between four and a half and six and a half hours after the initial temperature reading ;
TABLE 1

DRY AND WET-BULB TEMPERATURES AND AIR MOVEMENTS IN FIVE DISTRICTS IN ENUGU COLLIERY

\begin{tabular}{|c|c|c|c|c|c|}
\hline \multirow[t]{2}{*}{ District } & \multicolumn{2}{|c|}{$\begin{array}{l}\text { No. of obs. } \\
\text { made }\end{array}$} & \multicolumn{2}{|c|}{$\underset{\text { temperature }^{\circ} \mathrm{F} \text {. }}{\text { Air }}$} & \multirow{2}{*}{$\begin{array}{c}\text { Air } \\
\text { move- } \\
\text { ment } \\
\text { (ft. per } \\
\text { min.) }\end{array}$} \\
\hline & $\begin{array}{c}\text { on } \\
\text { hewers }\end{array}$ & $\begin{array}{c}\text { on } \\
\text { tubmen }\end{array}$ & $\begin{array}{l}\text { Dry } \\
\text { bulb }\end{array}$ & $\begin{array}{l}\text { Wet } \\
\text { bulb }\end{array}$ & \\
\hline $\begin{array}{l}\text { Main } \\
\text { Iva } 1\end{array}$ & $\begin{array}{l}2 \\
3 \\
2 \\
2 \\
0 \\
0 \\
1 \\
0 \\
0 \\
0\end{array}$ & $\begin{array}{r}0 \\
2 \\
1 \\
2 \\
11 \\
3 \\
0 \\
1 \\
2 \\
4\end{array}$ & $\begin{array}{l}85 \cdot 0 \\
88 \cdot 0 \\
88 \cdot 0 \\
88 \cdot 5 \\
87 \cdot 0 \\
91 \cdot 0 \\
86 \cdot 5 \\
88 \cdot 0 \\
90 \cdot 0 \\
90 \cdot 5\end{array}$ & $\begin{array}{l}83 \cdot 0 \\
86 \cdot 5 \\
86 \cdot 5 \\
86 \cdot 5 \\
86 \cdot 0 \\
90 \cdot 0 \\
84 \cdot 0 \\
86 \cdot 5 \\
89 \cdot 5 \\
89 \cdot 5\end{array}$ & $\begin{array}{l}22 \\
14 \\
44 \\
96 \\
86 \\
23 \\
50 \\
50 \\
38 \\
38\end{array}$ \\
\hline $\begin{array}{l}\text { Main } \\
\text { Iva } 2\end{array}$ & $\begin{array}{l}2 \\
3 \\
1 \\
1\end{array}$ & $\begin{array}{l}0 \\
0 \\
0 \\
0\end{array}$ & $\begin{array}{l}84 \cdot 0 \\
83.5 \\
85 \cdot 0 \\
86.5\end{array}$ & $\begin{array}{l}83 \cdot 0 \\
82.0 \\
83 \cdot 5 \\
85 \cdot 5\end{array}$ & $\begin{array}{l}98 \\
40 \\
14 \\
14\end{array}$ \\
\hline 23 East & $\begin{array}{l}2 \\
1 \\
2\end{array}$ & $\begin{array}{l}0 \\
2 \\
7\end{array}$ & $\begin{array}{l}86 \cdot 0 \\
83 \cdot 5 \\
86.0\end{array}$ & $\begin{array}{l}84 \cdot 0 \\
83 \cdot 0 \\
84 \cdot 0\end{array}$ & $\begin{array}{r}18 \\
150 \\
150\end{array}$ \\
\hline 34 West & $\begin{array}{l}3 \\
5 \\
2 \\
0 \\
2 \\
2 \\
0\end{array}$ & $\begin{array}{l}1 \\
7 \\
0 \\
3 \\
1 \\
0 \\
4\end{array}$ & $\begin{array}{l}88 \cdot 0 \\
83 \cdot 0 \\
85 \cdot 5 \\
84 \cdot 5 \\
87 \cdot 5 \\
87 \cdot 5 \\
87.0\end{array}$ & $\begin{array}{l}86 \cdot 5 \\
81 \cdot 5 \\
84 \cdot 0 \\
83 \cdot 0 \\
84 \cdot 0 \\
86 \cdot 0 \\
85.5\end{array}$ & $\begin{array}{r}14 \\
105 \\
50 \\
100 \\
20 \\
18 \\
20\end{array}$ \\
\hline 32 East & $\begin{array}{l}0 \\
2 \\
4 \\
4 \\
1 \\
4 \\
2\end{array}$ & $\begin{array}{r}1 \\
0 \\
1 \\
15 \\
0 \\
0 \\
0\end{array}$ & $\begin{array}{l}89.0 \\
90.5 \\
92.0 \\
93.0 \\
90.0 \\
90.0 \\
90.5\end{array}$ & $\begin{array}{l}88.5 \\
89.5 \\
92.0 * \\
92.0 \\
89.0 \\
89.5 \\
90.0\end{array}$ & $\begin{array}{r}133 \\
16 \\
10 \\
45 \\
20 \\
100 \\
160\end{array}$ \\
\hline
\end{tabular}

*Saturated 
TABLE 2

MEAN RECTAL TEMPERATURES IN EACH HALF HOUR PERIOD FROM THREE AND A HALF TO SEVEN AND A HALF HOURS AFTER THE INITIAL TEMPERATURE READING*

Part (a) Results according to day of observation and hence districts

\begin{tabular}{|c|c|c|c|c|c|c|c|c|c|c|c|}
\hline \multirow{2}{*}{\multicolumn{2}{|c|}{$\begin{array}{l}\text { Time after } \\
\text { initial obs. } \\
\text { (hours) }\end{array}$}} & \multicolumn{2}{|c|}{$\begin{array}{c}\text { Day } 1 \\
\text { Main Iva } 1\end{array}$} & \multicolumn{2}{|c|}{$\begin{array}{c}\text { Day } 2 \\
\text { M.I.2, } 23 \text { E. }\end{array}$} & \multicolumn{2}{|c|}{$\begin{array}{c}\text { Day } 3 \\
34 \text { West }\end{array}$} & \multicolumn{2}{|c|}{$\begin{array}{c}\text { Day } 4 \\
\text { 32 East }\end{array}$} & \multicolumn{2}{|c|}{ All days } \\
\hline & & Obs. & R.T. ${ }^{\circ} \mathrm{F}$. & Obs. & R.T. ${ }^{\circ} \mathrm{F}$. & Obs. & R.T. ${ }^{\circ} \mathrm{F}$. & Obs. & R.T. ${ }^{\circ} \mathrm{F}$. & Obs. & R.T. ${ }^{\circ} \mathrm{F}$. \\
\hline $\begin{array}{ll}3.30-3.59 & \ldots \\
4 \cdot 00-4.29 & \ldots \\
4.30-4.59 & \ldots \\
5.00-5.29 & \ldots \\
5.30-5.59 & \ldots \\
6.00-6.29 & \ldots \\
6.30-6.59 & \ldots \\
7.00-7.29 . & \ldots\end{array}$ & $\begin{array}{l}\ldots \\
\cdots \\
\cdots \\
\cdots \\
\cdots \\
\cdots\end{array}$ & $\begin{array}{r}1 \\
5 \\
15 \\
5 \\
1 \\
2 \\
0 \\
0\end{array}$ & $\begin{array}{c}99 \cdot 3 \\
100 \cdot 10 \\
100 \cdot 28 \\
100 \cdot 34 \\
99 \cdot 7 \\
99 \cdot 20\end{array}$ & $\begin{array}{l}0 \\
1 \\
8 \\
8 \\
7 \\
6 \\
4 \\
4 \\
1\end{array}$ & $\begin{array}{c}98 \cdot 4 \\
100 \cdot 02 \\
99 \cdot 70 \\
99 \cdot 20 \\
98.98 \\
98.90 \\
99.8\end{array}$ & $\begin{array}{r}0 \\
0 \\
12 \\
10 \\
6 \\
9 \\
1 \\
0\end{array}$ & $\begin{array}{l}99.86 \\
99.53 \\
99.65 \\
99.69 \\
98.9\end{array}$ & $\begin{array}{r}0 \\
1 \\
15 \\
11 \\
3 \\
4 \\
0 \\
0\end{array}$ & $\begin{array}{l}100 \cdot 0 \\
100 \cdot 27 \\
100 \cdot 06 \\
101 \cdot 43 \\
100 \cdot 20\end{array}$ & $\begin{array}{r}1 \\
7 \\
50 \\
34 \\
17 \\
21 \\
5 \\
1\end{array}$ & $\begin{array}{c}99 \cdot 3 \\
99 \cdot 84 \\
100 \cdot 14 \\
99 \cdot 87 \\
99 \cdot 77 \\
99 \cdot 54 \\
98 \cdot 90 \\
99 \cdot 8\end{array}$ \\
\hline \multicolumn{2}{|c|}{ Mean for all periods } & 29 & $100 \cdot 13$ & 35 & $99 \cdot 40$ & 38 & $99 \cdot 70$ & 34 & $100 \cdot 30$ & 136 & $99 \cdot 87$ \\
\hline
\end{tabular}

Part (b) Results grouped according to effective temperature of working place

\begin{tabular}{|c|c|c|c|c|c|c|c|c|c|c|c|}
\hline \multirow{2}{*}{$\begin{array}{c}\text { Time afte } \\
\text { initial obs } \\
\text { (hours) }\end{array}$} & & \multicolumn{2}{|c|}{$\begin{array}{c}\text { Group } A \\
\text { Above } 87 \cdot 1^{\circ} \mathrm{F} \text {. }\end{array}$} & \multicolumn{2}{|c|}{$\underset{83 \cdot 1-87 \cdot 0^{\circ} \mathrm{F} .}{\text { Group B }}$} & \multicolumn{2}{|c|}{$\underset{79 \cdot 1-83 \cdot 0^{\circ} \mathrm{F} .}{\text { Group }} \mathrm{C}$} & \multicolumn{2}{|c|}{$\underset{\text { Below } 79 \cdot 1^{\circ} \mathrm{F} \text {. }}{\text { Group }}$} & \multicolumn{2}{|c|}{ All groups } \\
\hline & & Obs. & R.T. ${ }^{\circ} \mathrm{F}$. & Obs. & R.T. ${ }^{\circ} \mathrm{F}$. & Obs. & R.T. ${ }^{\circ}$ F. & Obs. & R.T. ${ }^{\circ} \mathrm{F}$. & Obs. & R.T. ${ }^{\circ} \mathrm{F}$. \\
\hline $\begin{array}{ll}3.30-3.59 & \ldots \\
4.00-4.29 & \ldots \\
4.30-4.59 & \ldots \\
5.00-5.29 & \ldots \\
5.30-5.59 & \ldots \\
6.00-6.29 & \ldots \\
6.30-6.59 & \ldots \\
7.00-7.29 & \ldots\end{array}$ & $\begin{array}{l}\ldots \\
\ldots \\
\ldots \\
\ldots \\
\cdots \\
\cdots \\
\cdots\end{array}$ & $\begin{array}{r}0 \\
1 \\
15 \\
11 \\
3 \\
3 \\
0 \\
0\end{array}$ & $\begin{array}{l}100 \cdot 0 \\
100 \cdot 27 \\
100 \cdot 06 \\
101 \cdot 43 \\
100 \cdot 37\end{array}$ & $\begin{array}{r}0 \\
3 \\
20 \\
6 \\
0 \\
9 \\
2 \\
1\end{array}$ & $\begin{array}{r}99 \cdot 83 \\
100 \cdot 27 \\
100 \cdot 35 \\
\\
99 \cdot 83 \\
98 \cdot 90 \\
99 \cdot 8\end{array}$ & $\begin{array}{r}0 \\
3 \\
6 \\
8 \\
13 \\
4 \\
0 \\
0\end{array}$ & $\begin{array}{l}99 \cdot 80 \\
99.90 \\
99 \cdot 69 \\
99 \cdot 33 \\
98 \cdot 80\end{array}$ & $\begin{array}{l}1 \\
0 . \\
9 \\
9 \\
1 \\
5 \\
3 \\
0\end{array}$ & $\begin{array}{r}99 \cdot 3 \\
99 \cdot 79 \\
99 \cdot 43 \\
100 \cdot 60 \\
99 \cdot 10 \\
98 \cdot 90\end{array}$ & $\begin{array}{r}1 \\
7 \\
50 \\
34 \\
17 \\
21 \\
5 \\
1\end{array}$ & $\begin{array}{c}99 \cdot 3 \\
99 \cdot 84 \\
100 \cdot 14 \\
99 \cdot 87 \\
99 \cdot 77 \\
99 \cdot 54 \\
98.90 \\
99 \cdot 8\end{array}$ \\
\hline \multicolumn{2}{|c|}{ Mean for all periods } & 33 & $100 \cdot 33$ & 41 & $100 \cdot 05$ & 34 & $99 \cdot 48$ & 28 & $99 \cdot 47$ & 136 & $99 \cdot 87$ \\
\hline
\end{tabular}

* Observations on day 5 are not included as the time of observations was not recorded on this day.

the earliest observation was 3 hours 49 minutes, and the latest 7 hours 4 minutes after the first reading. The average for the whole series of $147 \dagger$ observations was $99.90^{\circ} \mathrm{F}$. The means for each half-hour period from three and a half to seven and a half hours after the initial reading were approximately the same; this was not only so for the whole series, but also for each district considered separately, and when the men were divided into groups according to the effective temperature, calculated from dry- and wet-bulb temperatures and air movement (Houghten and Yaglou, 1923) in which they were working; this is shown in Table 2. As rectal temperatures taken late in the shift were, on an average, no higher than those taken early, it was concluded that the men had reached a state of thermal equilibrium (Machle and Hatch, 1947) by the time the mid-shift measurements were taken.

The standard deviation from the mean was $0.78^{\circ} \mathrm{F}$. and the maximum and minimum temperatures recorded

+ Discrepancies between totals, here and elsewhere, are due to failure to find all the men underground, and to some men not having reported back for final readings. were $101 \cdot 8^{\circ} \mathrm{F}$. (three separate observations) and $98.0^{\circ} \mathrm{F}$. respectively. Eleven men, 8 hewers and 3 tubmen, had temperatures above $101^{\circ} \mathrm{F}$. and 4 were below $99 \cdot 0^{\circ} \mathrm{F}$ Men working in high effective temperatures in general had high rectal temperatures; Table 2 (b) in which the results have been grouped according to the effective temperature of the working place, shows this. An analysis of variance was carried out to test the statistical significance of this observation and also to determine whether the type of work had any effect upon the midshift rectal temperature ; the analysis, given in Table 3, shows that, when the whole series was considered as one, only working temperature had a significant effect upon mid-shift rectal temperature. The correlation coefficient between working effective temperature and rectal temperature was 0.43 ; this is significant, $t$ being 5.67 . Significant correlations were also obtained for rectal temperature with dry bulb and with wet bulb temperatures, with coefficients of $0.42, t=4.72$, and 0.37 , $t=5 \cdot 56$, respectively. Regression lines calculated from these coefficients are plotted in fig. 1 for effective temperature, and in fig. 2 for dry- and wet-bulb temperatures. 
TABLE 3

THE ANALYSIS OF VARIANCE FOR FACTORS AFFECTING MID-SHIFT RECTAL TEMPERATURES*

\begin{tabular}{|c|c|c|c|c|c|c|}
\hline \multirow{2}{*}{$\begin{array}{l}\text { Com- } \\
\text { parison } \\
\text { between }\end{array}$} & \multirow{2}{*}{ Df } & \multirow{2}{*}{$\begin{array}{c}\text { Sum } \\
\text { of } \\
\text { squares }\end{array}$} & \multirow{2}{*}{ Variance } & \multirow{2}{*}{$\mathrm{F}$} & \multicolumn{2}{|c|}{$\begin{array}{l}\text { Value of F } \\
\text { for }\end{array}$} \\
\hline & & & & & $\begin{array}{l}P= \\
0.05\end{array}$ & $\begin{array}{l}P= \\
0.01\end{array}$ \\
\hline $\begin{array}{l}\text { Works. } \\
\text { E. T.s . }\end{array}$ & $\begin{array}{r}1 \\
15\end{array}$ & $\begin{array}{r}0 \cdot 1033 \\
28 \cdot 7279\end{array}$ & $\begin{array}{l}0.1033 \\
1.9152\end{array}$ & $\begin{array}{l}0 \cdot 23 \\
4 \cdot 31\end{array}$ & $\begin{array}{l}253 \\
1 \cdot 73\end{array}$ & $\begin{array}{c}6,343 \\
2 \cdot 16\end{array}$ \\
\hline Error .. & 130 & $57 \cdot 7133$ & 0.4439 & - & - & - \\
\hline
\end{tabular}

* "F" statistic has been calculated according to Snedicor (1946). Factors investigated: (1) two types of work : (2) effective temperature of working place, sixteen groups, interval one degree $F$.

When the results were grouped according to the effective temperature of the working place, differences between hewers and tubmen were seen. Above $87 \cdot 1^{\circ} \mathrm{F}$., group A, hewers had significantly higher rectal temperatures than tubmen ; when the working effective temperature was between 83.1 and $87.0^{\circ} \mathrm{F}$., group $\mathrm{B}$, or between 79.1 and $83.0^{\circ} \mathrm{F}$., group $\mathrm{C}$, tubmen had slightly higher temperatures than hewers, but the difference was not significant; below $79 \cdot 1^{\circ} \mathrm{F}$, group $\mathrm{D}$, the tubmen's temperatures were significantly higher than the hewer's. The statistics are shown in Table 4. The correlation caefficient between the mid-shift rectal temperatures of hewers and the effective temperature of their working place was $0.49, t=4.81$. The corresponding regression line has been plotted in fig. 1 , where it is seen to cross the line for the whole series.

(b) Final Rectal Temperatures.-Final rectal temperature readings were taken mainly between eight and a half and nine and a half hours after the initial reading; the earliest was taken at 8 hours 10 minutes after, and the latest at 9 hours 44 minutes. Neither time of observation, nor place of work, nor temperature of working place appeared to affect the final rectal temperature. The means for the different days were $100 \cdot 55,100 \cdot 37$, $100 \cdot 50$, and $100 \cdot 48^{\circ} \mathrm{F}$. for days $1,2,3$, and 4 respectively ; these means did not differ significantly from each other or from the mean of the whole 147 observations, $100 \cdot 47^{\circ}$ F. $( \pm 0.04$, S.E. of mean); the standard deviation was 0.51. When the results were grouped according to the effective temperature of the working places, the means were : group A, $100 \cdot 46^{\circ}$ F.; group B, $100 \cdot 48^{\circ}$ F. ; group $\mathrm{C}, 100 \cdot 33^{\circ} \mathrm{F}$.; group $\mathrm{D}, 100 \cdot 55^{\circ} \mathrm{F}$. Twenty-two men had final rectal temperatures above $101^{\circ} \mathrm{F}$., and two were above $102^{\circ} \mathrm{F}$. The lowest final rectal temperature was $99 \cdot 0^{\circ} \mathrm{F}$.

Weight Loss and Water Balance.-The mean loss in body weight during a single shift by 315 men was $1.76 \mathrm{~kg}$. ( \pm 0.04, S.E. of mean). The greatest loss was by those working in effective temperature range $C, 79 \cdot 1$ to $83.0^{\circ}$ F. ; there was thus no correlation with working temperature. Weight loss was not affected by type of work : the mean loss by 127 hewers was $1.75 \mathrm{~kg}$., and by 188 tubmen $1.77 \mathrm{~kg}$. The standard deviation from the mean was $0.75 \mathrm{~kg}$., but 22 men lost more than $3 \mathrm{~kg}$. and only 8 lost less than $0.5 \mathrm{~kg}$. ; this skewness was statistically significant, the $g_{1}$ statistic (Fisher, 1941) being 0.438 , for which with 315 observations $P$ is less than 0.01 . The pre-shift weights ranged from $47.5 \mathrm{~kg}$. to $80.5 \mathrm{~kg}$. with the mean at $59.57 \mathrm{~kg}$.

Urine was obtained from 147 men coming off shift; volumes up to $200 \mathrm{c} . \mathrm{cm}$. were collected, and the mean was $70 \mathrm{c.cm}$. The mean chloride content, estimated by the Fantus method (see below) was 0.86 per cent., expressed as sodium chloride ; in only 2 specimens, both very dilute, was there too little chloride to estimate, in 15 the concentration was 1.5 per cent. or over. Temperature of working place had no obvious effect on either quantity or quality of the urine.

Composition of Sweat.-Sweat was obtained for estimation of its chloride content by means of arm-bags (Ladell, 1945) from 4 timbermen, performing a set task underground, and from 6 hewers and 4 tubmen in the course of their actual work. The arms and the bags were washed in tap-water which contained no chloride titratable by Whitehorn's method.

Chloride was estimated by the Fantus method (Fantus, 1936); this is a qualitative method which can be used quantitatively. To ten drops of urine is added one drop of 20 per cent. potassium chromate solution; it is then titrated with 2.9 per cent. silver nitrate solution until the colour changes to brown; the number of drops of silver solution used gives the number of parts of chloride, as sodium chloride, per thousand of solution being tested. In the present instance decimils were used instead of drops, and the method was

TABLE 4

COMPARISON BETWEEN THE RECTAL TEMPERATURES OF HEWERS AND OF TUBMEN, IN DIFFERENT RANGES OF WORKING EFFECTIVE TEMPERATURE -

\begin{tabular}{|c|c|c|c|c|c|c|c|}
\hline \multirow{2}{*}{ Group } & \multirow{2}{*}{$\begin{array}{c}\text { Effective } \\
\text { temperature range }\end{array}$} & \multicolumn{2}{|c|}{ Hewers } & \multicolumn{2}{|c|}{ Tubmen } & \multicolumn{2}{|c|}{ Comparison between means } \\
\hline & & No. & R.T. ${ }^{\circ} \mathrm{F}$. & No. & R.T. ${ }^{\circ} \mathrm{F}$. & $t$ & Probability \\
\hline $\begin{array}{l}\mathbf{A} \\
\mathbf{B} \\
\mathbf{C} \\
\mathbf{D}\end{array}$ & $\begin{array}{c}\text { Above } 87 \cdot 1^{\circ} \mathrm{F} \text {. } \\
83 \cdot 1-87 \cdot 0 \\
79 \cdot 1-83 \cdot 0 \\
\text { below } 79 \cdot 1\end{array}$ & $\begin{array}{l}22 \\
20 \\
16 \\
15\end{array}$ & $\begin{array}{r}100 \cdot 6 \\
100 \cdot 03 \\
99 \cdot 32 \\
99 \cdot 25\end{array}$ & $\begin{array}{l}20 \\
23 \\
18 \\
13\end{array}$ & $\begin{array}{r}100 \cdot 05 \\
100 \cdot 15 \\
99 \cdot 68 \\
99 \cdot 64\end{array}$ & $\begin{array}{l}2 \cdot 84 \\
0 \cdot 69 \\
1 \cdot 55 \\
2 \cdot 30\end{array}$ & $\begin{array}{l}\text { less than } 0.01 \\
\quad 0.5 \\
\text { approx. } 0.15 \\
\text { approx. } 0.03\end{array}$ \\
\hline
\end{tabular}




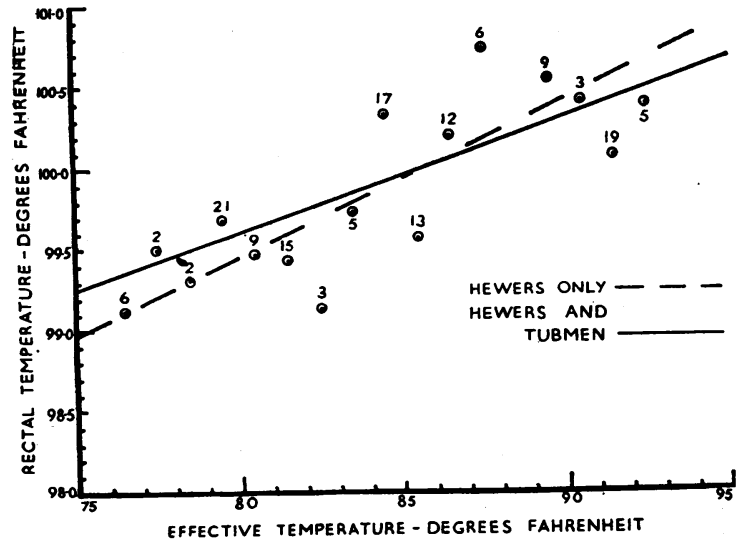

FIG. 1.-Regressions for mid-shift rectal temperature with effective temperature of working place. Solid line: Hewers and tubmen, 147 observations: (Line is drawn to equation: R.T. $=0.070$ E.T.+ 93.95.) Broken line: Hewers only, 74 observations. (Line is drawn to equation: R.T. $=0.096$ E.T.+ 91.78.) Points show the group means, hewers and tubmen together; grouping interval one degree F. of effective temperature. Figures next to the points give the number observed in each group.

calibrated against sodium chloride solutions of known strength, from 0.1 to 2.0 per cent. When the titration was done slowly a constant error of one decimil in excess was found; as all the titrations in this investigation had been done slowly, the necessary correction has been applied to the results.

The mean chloride content of 19 samples of sweat from the 4 timbermen was 0.18 per cent., as sodium chloride ; the lowest value was 0.17 per cent. and the highest 0.33 per cent. The chloride content of the sweats from the hewers and tubmen ranged from 0.08 per cent. to 0.33 per cent., with the mean 0.25 per cent. These values are within the range found for Europeans in warm countries, for example, British soldiers in Iraq (Ladell and others, 1944). Weiner (personal communication) found that fresh sweat from Bantu mineworkers had a characteristic odour; no odour was noticed with sweat from these miners.

\section{Discussion}

The height of the mid-shift rectal temperatures showed that the conditions were as severe as the air temperatures and humidities and air movements suggested; but casualties from the heat have not been reported in this mine. One fitness test done, inconclusive by itself and not now reported, suggested that the African miners were less able to work in severe heat than fully acclimatized Europeans : hence the lack of heat illness cannot be attributed to any special tolerance of these men to heat.

The men do not work continuously; on a tour round the mine as many men were seen resting as working, and many of the temperatures recorded were taken after partial recovery. When the sweat samples were being taken the men were told to carry on with their work and to take no rest during the collecting period; rectal temperatures were taken at the beginning and end of this, and in only two cases was there no rise: The mean rise for 7 hewers in a mean period of 29 minutes was $0.45^{\circ} \mathrm{F}$., and for 4 tubmen in a mean period of 19 minutes was $0.55^{\circ} \mathrm{F}$. The European overmen recognize that frequent rests are necessary and, unofficially, allow the hewers to double up in the hotter districts. This is probably the saving factor. No working place, no matter how hot and airless, is far from a well ventilated and cooler road, and any man can get away for a few minutes and cool off if he needs to. An example of this occurred during the sweat collections : in 35 minutes hewing, in air at dry bulb $90.5^{\circ} \mathrm{F}$. and wet bulb $89.5^{\circ} \mathrm{F}$., air movement $38 \mathrm{ft}$./min., one man's temperature rose from 101.8 to $102.6^{\circ} \mathrm{F}$., he stopped sweating and his skin became bone dry ; but he was sent off to a cool road and did not become a casualty.

The cooling effect of the well-ventilated roads may account for the differences observed between the rectal temperatures of hewers and those of tubmen. In the hotter districts the tubmen have to go out into the roads in the course of their work and so may cool off a little; but the hewers usually take their rest periods in the hot, airless, robberies and developments, where the only air movement is that provided by the men themselves by palmleaf fans,

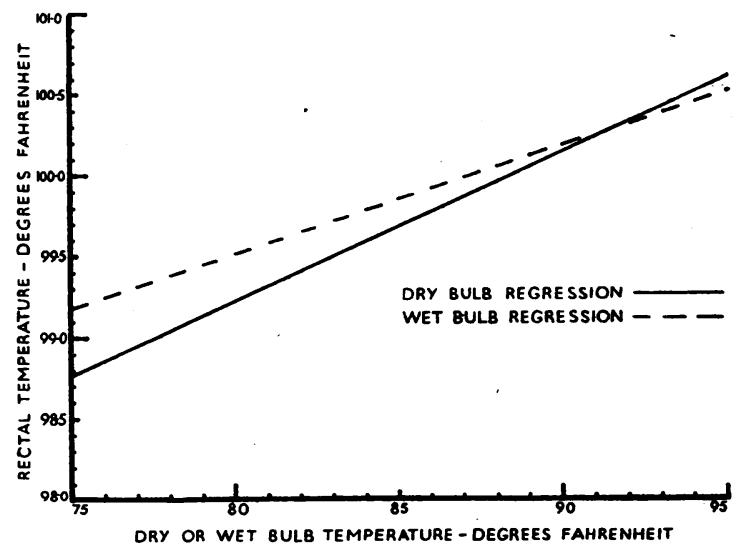

FIG. 2.-Regressions for mid-shift rectal temperatures of 147 hewers and tubmen with (a) dry-bulb temperature and $(b)$ wet-bulb temperature of the working place. Solid line: with dry bulb. (Drawn to equation : R.T. $=0.093$ D.B.+91-79.) Broken line : with wet bulb. (Drawn to equation: R.T.0.067 W.B. +94.14.) 
/which they all carry. In the cooler districts rectal temperatures are lower for all, but there is less contrast between face and roads, so the tubmen do not cool off relative to the hewers; in fact they remain at a higher rectal temperature than the hewers. This suggests that their work, which is continuous, is more gruelling than hewing, which is intermittent.

Final rectal temperatures were independent of type of work, or of temperature of working place ; they were, however, higher than the mid-shift temperatures which represented the steady state of the men at work under the particular conditions holding. Final temperatures, therefore, probably represented some other stress common to all districts and works. Actual rises in rectal temperature, from mid-shift to end of shift, were in general greater among those men from the more distant districts; the high final rectal temperatures may then have represented the effect of the walk back from the working place to the bank. The actual rise in some cases was $1^{\circ} \mathrm{F}$.; this indicates considerable physiological stress.

As most of the men took food into the mine, usually a piece of yam, the weight loss during the shift was mainly due to voluntary dehydration (Rothstein and Adolph, 1944 ; Eichna and others, 1945). The water intake during work could not be estimated as the men drank freely from springs which were all along the roads. The losses observed were less than those reported by Caplan (1943) for men doing intermittent work in the Kolar gold mines; there voluntary dehydration developed at from 0.7 to $1.51 . / \mathrm{hr}$. The actual sweat losses at Enugu may have been as much as $11 . / \mathrm{hr}$. in some cases and from the observed chloride of the sweat this means salt losses of $15 \mathrm{~g}$. or more per shift ; but no signs of salt deficiency were seen and all the urines examined had good concentrations of chloride, except for two. As the men sweat apart from their work, their salt intake must be considerable ; these men are, in fact, known to be heavy salt eaters.

\section{Summary}

1. Rectal temperatures of hewers and of tubmen taken in the middle of the shift were statistically correlated with the air temperatures at the working place.

2. The mean weight loss during a single shift was $1.76 \mathrm{~kg}$. Some men lost more than $3 \mathrm{~kg}$. ; there was no correlation between weight loss and working temperature.

3. The chloride content of sweat obtained from the African miners was comparable with that of sweat from Europeans living in the heat.

4. No casualties from the heat were seen, nor have any been reported.

I thank my wife for her very great assistance throughout ; many of the observations were made by her. I am grateful to the management of the Government Colliery, Enugu, for the facilities generousl afforded me, and to the Director of Medical Services, Nigeria, for his permission to make and to report upon this investigation. The work was sponsored and financed by the Colonial Medical Research Committee, to whom a more detailed report has been made.

\section{REFERENCES}

Caplan, A. (1943). Trans. Inst. Mining Metall., 53, 95.

Eichna, L. W., Bean, W. B., Ashe, W. F., and Nelson, N. (1945) Johns Hopkins Hosp. Bull., 76, 25.

Fantus, J. B. (1936). J. Amer. med. Ass., 107, 14.

Fisher, R. A. (1941). "Statistical Methods for Research Workers." 8th Edit. Edinburgh. Oliver and Boyd.

Houghten, F. C., and Yaglou, C. P. (1923). J. amer. Soc. heat. vent. Eng., 29, 165.

Ladell, W. S. S. (1945). Brit. med. Bull., 3, 175. Waterlow, J. C., and Hudson, M. F. (1944). Lancet, 2, 49 and 527.

Machle, W., and Hatch, T. F. (1947). Physiol. Rev., 27, 200.

Rothstein, A., and Adolph, E. F. (1944). Interim reports on project OEM Mrmr 206, No. 16 .

Snedicor, G. W. (1946). "Statistical methods." 4th Edit. Iowa. Collegiate Press. 